\title{
Calculation of the main technological parameters of the apparatus for receiving raw materials used in the production of medical application sorbent
}

\author{
(C) Ilnar A. Valeev, ${ }^{+}$Irina V. Zhukova, ${ }^{*+}$ and Azat A. Girfanutdinov \\ Department of Medical Engineering. Kazan National Research Technological University. Karl Marx St., 68. \\ Kazan, 420015. Tatarstan Republic. Russia.Phone: +79172751463.E-mail: zhukovka116@mail.ru
}

\begin{abstract}
*Supervising author; ${ }^{+}$Corresponding author Keywords: waste wood, charcoal, activated carbon, pyrolysis, pyrolysis plants, plants for charcoal burning, sorbents, activated carbon, enterosorbents, sorbents for medical purposes.
\end{abstract}

\begin{abstract}
Analysis of the consumption of activated carbon on the international market showed sufficient demand for this topic, both for medical and for most industries. Sorbents are a large class of drugs that are able to excrete a wide variety of toxic substances from the body. The activated carbon market in the Russian Federation was focused on the military-industrial complex, due to which the range of goods was very limited. Due to the current situation, activated carbons produced by our industry are universal and, therefore, ineffective for specific tasks. Based on this, the problem of inexpensive and effective sorbents is very relevant and the lack of active coal reaches several tens of thousands per year. This problem is being solved for the most part by importing the product. The urgency of the problem poses the task of quickly introducing this type of installation and effectively calculating its technical parameters for subsequent manufacturing. The task of the engineering method of calculation is the operational calculation of the given source data, the design parameters of the apparatus. The possibility of using waste wood processing enterprises has shown that the use of this type of raw material is justified and effective. Both in terms of cost, and in terms of beneficial use of tree illiquid. Technical innovations and proven solutions used in the experimental setup will significantly intensify the pyrolysis process while improving product quality and reducing its cost. An algorithm for calculating the main technical parameters of the camera. It includes several blocks responsible for each parameter. Calculation of geometric parameters allows you to develop an installation of strictly the required geometric size based on the necessary raw materials needs. Aerodynamic calculation takes into account the whole process of preparing raw materials and allows you to select the necessary attachments strictly according to the required parameters. Thermal calculation allows you to select the materials of the chamber from the required temperature range required for more efficient raw materials production with the optimal characteristics.
\end{abstract}

\section{References}

[1] I.A. Valeev., R.G. Safin, A.N. Grachev, P.A. Kainov, V.N. Bashkirov. Thermal utilization of waste from wood processing industry. Forest Bulletin. 2008. No.4. P.71-76. (russian)

[2] A.N. Grachev, I.A. Valeev, R.G. Safin, D.A. Khalitov, A.N. Nikolaev, V.I. Petrov. Thermochemical processing of wood by rapid pyrolysis. Woodworking industry. Moscow. 2009. No.3. P.21-24. (russian)

[3] R.R. Khasanshin, R.V. Danilova. Preliminary heat treatment of wood filler in the production of dpkt. Bulletin of the Kazan state technological University. Kazan. 2012. No.7. P.62-63. (russian)

[4] N.R. Galyavetdinov, F.G. Valiev, R.R. Khasanshin. Assessment of the effect of heat treatment of wood filler on the performance properties of cement-bonded particle board. Bulletin of Kazan Technological University, Kazan, KNRTU. 2012. Vol.15. No.10. P.85-87. (russian)

[5] I.A. Valeev. Mathematical modeling of the wood pyrolysis process when regulating the medium pressure. Woodworking Industry. 2012. No.3. P.41-46. (russian)

[6] I.Z. Fayzullin, I.V. Imamutdinov, V.Y. Khamidov, I.N. Musin, S.I. Wolfson. Influence of fillers and technological additives on the rheological properties of wood - polymer composites. Bulletin of the Kazan technological University, Kazan, KNRTU. 2013. Vol.16. No.10. P.148-150. (russian)

[7] I.N. Musin, I.Z. Fayzullin, S.I. Wolfson. The influence of filler particle size on the properties of woodpolymer composites. Bulletin of the Kazan technological University, Kazan, KNRTU. 2013. Vol.16. No.5. P.106-109. (russian)

[8] S.I. Volfson, I.N. Musin, I.Z. Faizullin, T.Z. Lygina, F.A. Trofimova. Modified wood-polymer composites. Journal "Plastic mass", Moscow. 2014. No.1-2. P.41-44. (russian)

[9] I.N. Musin, I.Z. Fayzullin, S.I. Wolfson. Modification of wood-polymer composites based on polyolefins with montmorillonite. Bulletin of the Kazan technological University, Kazan, KNRTU. 2012. No.14. P.135-138. (russian) 